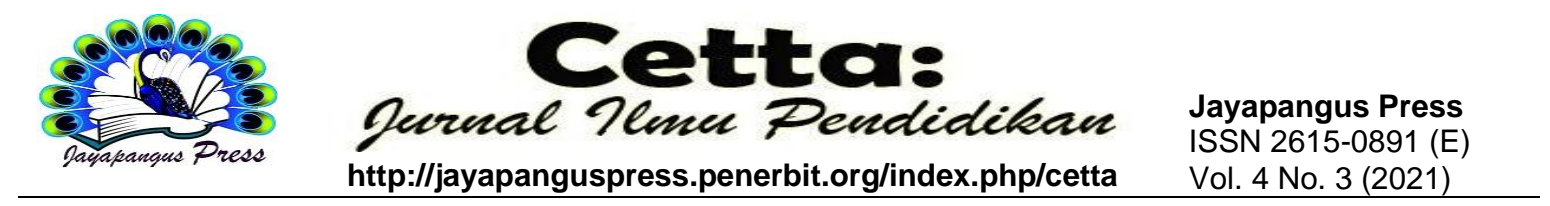

\title{
Penerapan Model Pembelajara cooperative Tipe Think Talk Write (TTW) dalam Upaya Meningkatkan Aktivitas dan Hasil Belajar Matematika Pada Siswa Kelas V SD Negeri 4 Seraya Barat
}

\author{
I Komang Sulitra Astawan \\ SD Negeri 4 Seraya Barat \\ komangsulitraastawan75@gmail.com
}

\begin{tabular}{l}
\hline Keywords: \\
\hline Learning model; \\
Cooperative Type \\
Think Talk Write \\
(TTW); Learning \\
outcomes \\
\hline
\end{tabular}

Kata Kunci:

Penerapan Model

Pembelajaran;

Cooperative Tipe

Think Talk Write

(TTW); Hasil

Belajar

\begin{abstract}
This research was conducted at SD Negeri 4 Seraya Barat. This type of research is classroom action which is carried out in two cycles. The subjects of this study were the $V$ grade students of $S D$ Negeri 4 Seraya Barat in the odd semester of the 2019/2020 school year, totaling 14 people. Each cycle consists of four stages of activities, namely planning, implementing actions, observing, evaluating, and reflecting. The data collected in this study are: (1) student activities, and (2) student learning outcomes. Based on the results of data analysis and discussion of this research, the following conclusions can be drawn. 1) The application of the Think Talk Write (TTW) cooperative learning model in mathematics learning can improve the learning activities of fifth grade students at SD Negeri 4 Seraya Barat in the odd semester of the 2019/2020 school year. Student learning activity in Cycle I was 10.64 while student learning activity in Cycle II was 14.43. Thus there was an increase of 3.79 from cycle I to cycle II. 2) The application of the Think Talk Write (TTW) cooperative learning model in mathematics learning can improve the learning outcomes of fifth graders at SD Negeri 4 Seraya Barat in the odd semester of the 2019/2020 school year. Student learning outcomes in cycle I were 73.93 while student learning outcomes in cycle II were 90.36, thus an increase of 16.43 from cycle I to cycle II.
\end{abstract}

\begin{tabular}{l} 
Abstrak \\
\hline Penelitian ini dilakukan di SD Negeri 4 Seraya Barat. Jenis \\
penelitian ini adalah tindakan kelas yang pelaksanaannya \\
dilakukan dalam dua siklus. Subjek penelitian ini adalah siswa \\
kelas V SD Negeri 4 Seraya Barat pada semester ganjil tahun \\
pelajaran 2019/2020 yang berjumlah 14 orang. Setiap siklus \\
terdiri dari empat tahap kegiatan yaitu perencanaan, pelaksanaan \\
tindakan, observasi, evaluasi, dan refleksi. Data yang \\
dikumpulkan dalam penelitian ini adalah: (1) Aktivitas siswa, \\
dan (2) hasil belajar siswa. Berdasarkan hasil analisis data dan \\
pembahasan penelitian ini dapat ditarik simpulan sebagai
\end{tabular}


berikut. 1) Penerapan model pembelajaran cooperative tipe Think Talk Write (TTW) dalam pembelajaran matematika dapat meningkatkan aktivitas belajar siswa kelas V SD Negeri 4 Seraya Barat semester ganjil tahun pelajaran 2019/2020. Aktivitas belajar siswa pada Siklus I adalah 10,64 sedangkan aktivitas belajar siswa pada siklus II adalah 14,43. Dengan demikian terjadi peningkatan sebesar 3,79 dari siklus I ke siklus II. 2) Penerapan model pembelajaran cooperative tipe Think Talk Write (TTW) pada pembelajaran matematika dapat meningkatkan hasil belajar siswa kelas V SD Negeri 4 Seraya Barat semester ganjil tahun pelajaran 2019/2020. Hasil belajar siswa pada siklus I adalah 73,93 sedangkan hasil belajar siswa pada siklus II adalah 90,36, dengan demikian terjadi peningkatan sebesar 16,43 dari siklus I ke siklus II.

\section{Pendahuluan}

Fenomena yang muncul belakangan ini menunjukkan bahwapembelajaran matematika dianggap kurang dapat memberikan kontribusi yang maksimal dalam meningkatkan mutu pendidikan. Permasalahan ini terjadi di Satuan Pendidikan SD Negeri 4 Seraya Barat. Dalam proses pembelajaran sering mendapatkan kendala seperti minimnya sarana penunjang dalam pembelajaran, terbatasnya buku-buku matematika, menyebabkan beberapa guru yang mengajar sebatas apa adanya. Dengan demikian berimplikasi bagi guru dalam pembelajaran seperti gairah mengajar semakin menurun sehingga berdampak pada menurunnya aktivitas dan hasil belajar siswa. Minimnya pemilihan model-model pembelajaran yang inovatif dan variatif. Tantangan lain yang ditemukan di sekolah ini adalah : banyak siswa yang sulit untuk mengerti materi pelajaran yang diajarkan oleh guru, pembelajaran masih bersifat teoretis sehingga siswa akan mudah merasa jenuh dan bosan dalam menerima pelajaran, sistem pembelajaran masih cenderung menggunakan gaya konvensional, sehingga siswa hanya diam dan tidak timbul aktivitas, guru lebih mendominasi kegiatan, sehingga bisa menghilangkan antusias siswa terhadap materi pembelajaran, rendahnya minat siswa untuk belajar matematika terutama dalam menerima dan mengerjakan tugas yang diberikan oleh guru, hasil belajar siswa dalam pembelajaran matematika cenderung masih rendah atau masih di bawah kriteria ketuntasan minimal. Matematika yang merupakan bagian dari mata pelajaran Ujian Nasional (UN) mesti lebih mendapatkan perhatian.

Matematika sebagai mata pelajaran yang dianggap berperan lebih dalam menentukan kelulusan bagi siswa.Pemberian nilai matematika dipaksakan harus tuntas walaupun rimidialnya masih rendah. Dari fakta-fakta yang ada seolah-olah menunjukkan 
bahwa matematika merupakan mata pelajaran yang ditakuti oleh siswa. Dilihat dari hasil tes pra siklus masih banyak siswa yang mendapat nilai di bawah KBM. Pencapaian nilai tes terendah adalah 20 sedangkan nilai tertinggi adalah 100 dengan rata-rata hasil belajar hanya 57,85, sedangkan Kriteria Ketuntasan Minimal yang ditetapkan di Satuan Pendidikan SD Negeri 4 Seraya Barat adalah 65 dengan hasil tersebut memperlihatkan bahwa hasil belajar matematika siswa kelas $\mathrm{V}$ masih belum maksimal. Dalam mengoptimalkan pembelajaran matematika salah satunya perlu adanya strategi yang tepat dalam proses belajar mengajar.

Dalam memilih strategi pengajaran yang tepat perlu memperhatikan beberapa hal seperti materi yang akan disampaikan, tujuan, waktu yang disediakan dan banyaknya siswa serta hal-hal berkaitan dengan proses belajar mengajar. Stategi pembelajaran yang dapat mendorong siswa untuk ikut aktif adalah model pembelajaran cooperative. Menurut Saptono (2009) cooperative learning merupakan strategi pembelajaran yang mengutamakan kelompok siswa dengan kemampuan akademik yang berbeda melalui kolompok-kelompok kecil. Pembelajaran kooperatif dapat membantu siswa meningkatkan sikap positif dalam pembelajaran matematika dan membangun kepercayaan diri dalam menyelesaikan masalah matematika, sehingga hilangnya rasa takut dan khawatir pada dirinya.

Model pembelajaran cooperative. terdapat berbagai macam model, diantaranya strategi pembelajaran Think Talk Write (TTW). Menurut Marisanita (2009) strategi ini dapat menumbuhkembangkan keaktifan siswa dan kreativitas berpikir siswa. Alur Pembelajaran Strategi Think Talk Write yaitu dimulai dengan berpikir melalui bahan bacaan (menyimak, mengkritisi, dan alternatif solusi), hasil bacaan tersebut kemudian dikomunikasikan dengan presentasi, sehingga diharapkan siswa dapat berinteraksi langsung antar guru dan siswa, siswa dengan siswa. Think Talk Write (TTW). dapat melibatkan siswa untuk berpikir kritis, selajutnya berbicara atau berdiskusi dengan teman kelompok dan mencatat hasil diskusi. Kelompok akan lebih efektif apabila dilakukan dalam kelompok yang heterogen antara 3-5 orang siswa (dalam hal kemampuan, prestasi, gender, minat dan sikap).

Dari pendapat tersebut dapat disimpulkan bahwa strategi pembelajaran Think Talk Write $(T T W)$. merupakan suatu strategi yang yang dapat menumbuhkembangkan siswa baik dalam berpikir, berdiskusi dan menuliskannya secara aktif khususnya dalam pembelajaran matematika. 


\section{Metode}

\section{Tempat dan Waktu Penelitian}

Penelitian ini dilakukan di Satuan Pendidikan SD Negeri 4 Seraya Barat Dalam rencana penelitian ini, waktu pelaksanaannya dirancang pada semester ganjil tahun pelajaran 2018/2019.

\section{Rancangan Penelitian}

Jenis penelitian ini adalah tindakan kelas yang pelaksanaannya dilakukan dalam dua siklus. Ada beberapa model atau desain dalam penelitian tindakan kelas. Namum, pada prinsipnya setiap model tersebut hampir sama sebagaimana yang dikemukakan oleh Wibawa (2003:35), Arikunto (2006:92), dan Wardani (2004:24), masing-masing siklus terdiri atas empat tahapan yaitu: (1) perencanaan tindakan, (2) pelaksanaan tindakan, (3) observasi dan evaluasi, serta (4) refleksi tindakan. Akan tetapi sebelum siklus dilakukan terlebih dahulu dilaksanakan refleksi awal.

\section{Subjek dan Objek Penelitian}

Subjek penelitian ini adalah siswa kelas V Satuan Pendidikan SD Negeri 4 Seraya Barat pada semester ganjil tahun pelajaran 2019/2020 yang berjumlah 14 orang. Siswa laki-laki sebanyak 07 orang dan siswa perempuan sejumlah 06 orang sedangkan objek penelitian ini adalah Penerapan Model Pembelajaran cooperative tipe Think Talk Write $(T T W)$.

\section{Prosedur Penelitian}

Penelitian Tindakan Kelas (PTK) dilaksanakan berkolaborasi antara guru kelas yang lainya dengan peneliti. Kerja sama secara bertahap dilakukan secara maksimal agar Aktivitas dan hasil belajar dapat dicapai secara maksimal. Kerja sama yang dimaksudkan mulai dari tahap orientasi sehingga akan dapat mencapai kesempurnaan pada setiap siklusnya. Semua ini bertujuan untuk meningkatkan aktivitas dan hasil belajar matematika bagi siswa kelas V Satuan Pendidikan SD Negeri 4 Seraya Barat. Data yang dikumpulkan dalam penelitian ini adalah: (1) Aktivitas siswa, dan (2) hasil belajar siswa. 


\section{Hasil Dan Pembahasan}

\section{Hasil Penelitian pada Siklus I}

a. Hasil Aktivitas Siswa Siklus I

Data tentang aktivitas belajar pada siklus I diperoleh melalui lembar observasi selama kegiatan pembelajaran berlangsung. Lembar observasi tersebut terdiri atas 5 (lima) indikator yang masing-masing indikator mempunyai skor maksimum 4 dan skor minimum 0 , artinya siswa diberikan skor 4 jika memenuhi keempat deskriptor yang ada pada setiap indikator dan siswa akan diberikan skor 0 jika tidak ada memenuhi keempat deskriptor yang ada pada setiap indikator. Berdasarkan penggunaan rumus di atas, dapat ditentukan katagori aktivitas belajar siswa dengan menggunakan tabel aktivitas belajar, seperti tabel 1 berikut.

Tabel 1. Katagori Aktivitas Belajar Siswa

$\begin{array}{cll}\text { No } & \text { Skor } & \text { Katagori } \\ \text { 1. } & \bar{X} \geq \mathrm{Mi}+1,5 \mathrm{SDi} & \text { Sangat Aktif } \\ \text { 2. } & \mathrm{Mi}+0,5 \mathrm{Sdi} \leq \bar{X}<\mathrm{Mi}+1,5 \mathrm{Sdi} & \text { Aktif } \\ \text { 3. } & \mathrm{Mi}-0,5 \mathrm{Sdi} \leq \bar{X}<\mathrm{Mi}+0,5 \mathrm{Sdi} & \text { Cukup Aktif } \\ \text { 4. } & \mathrm{Mi}-1,5 \mathrm{Sdi} \leq \bar{X}<\mathrm{Mi}-0,5 \mathrm{Sdi} & \text { Kurang Aktif } \\ \text { 5. } & \bar{X}<\mathrm{Mi}-1,5 \mathrm{Sdi} & \text { Sangat Kurang Aktif }\end{array}$

(Arikunto, 2005:180)

Berdasarkan tabel perolehan aktivitas belajar siswa dapat diketahui bahwa siswa yang berada pada katagori sangat aktif sebanyak 0 orang $(0,00 \%)$; siswa yang berada pada katagori aktif sebanyak 6 orang $(42,86 \%)$; siswa yang berada pada katagori cukup aktif sebanyak 4 orang $(28,57 \%)$; dan siswa yang berada dalam katagori kurang aktif sebanyak 4 orang $(28,57 \%)$.

Kemudian dari skor yang diperoleh dicari rata-rata untuk mengkategorikan sejauh mana aktivitas belajar siswa terhadap penerapan model pembelajaran cooperative tipe Think Talk Write (TTW) dalam pembelajaran matematika siswa kelas V Satuan Pendidikan SD Negeri 4 Seraya Barat semester ganjil Tahun Pelajaran 2019/2020. Untuk lebih jelasnya, data aktivitas siswa dihitung dengan rumus sebagai berikut.

$$
\bar{X}=\frac{\Sigma X}{N}
$$

Keterangan:

$$
\bar{X} \quad=\text { nilai rata-rata kelas }
$$


$\Sigma X=$ jumlah nilai siswa keseluruhan

$\mathrm{N}=$ jumlah siswa

$\bar{X}=\frac{\Sigma X}{\frac{N}{14}}=\frac{149}{14}=10,64$

Sesuai dengan kriteria aktivitas, tingkat kategori aktivitas siswa dengan penerapan model pembelajaran cooperative tipe Think Talk Write (TTW) dalam upaya meningkatkan aktivitas dan hasil belajar matematika siswa kelas V Satuan Pendidikan SD Negeri 4 Seraya Barat tahun pelajaran 2019/2020, pada siklus I tergolong cukup aktif. Hal itu dapat dilihat pada grafik berikut.

Gambar 1. Grafik Aktivitas Belajar Siswa Siklus I

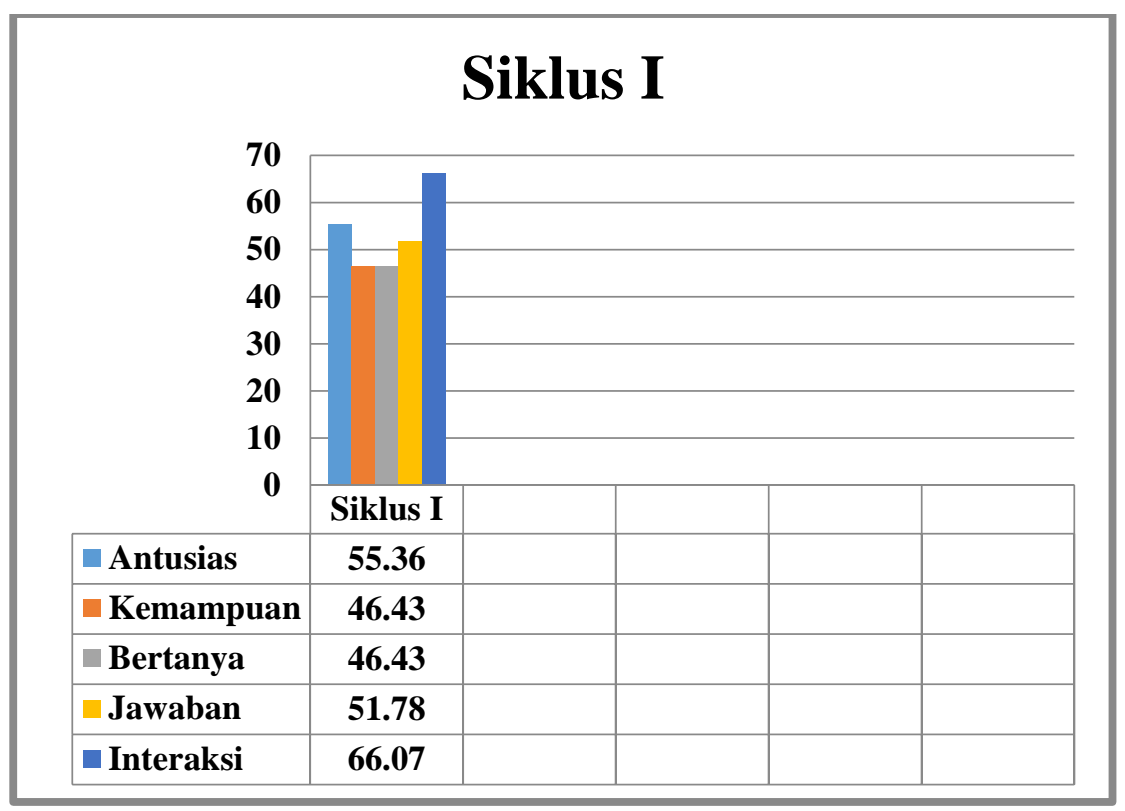

b. Hasil Belajar Siswa Siklus I

Hasil belajar siswa pada siklus I dalam penerapan model pembelajaran cooperative tipe Think Talk Write (TTW) dalam upaya meningkatkan aktivitas dan hasil belajar matematika siswa kelas V Satuan Pendidikan SD Negeri 4 Seraya Barat semester ganjil Tahun Pelajaran 2019/2020, yang dikumpulkan melalui tahap evaluasi siklus I diperoleh skor 2035 dengan skor maksimum idealnya adalah 1400 dan skor minimal idealnya adalah 0 yang sudah dikonversikan ke dalam skor 100. Salah satu contoh pengolahan hasil belajar siswa adalah sebagai berikut.

Skor mentah

$$
X S 1=, \overline{\text { soal }} \times 100
$$

15

$\mathrm{XS} 1=-\times 100=75$ 
Berdasarkan perolehan hasil belajar tersebut dapat diketahui bahwa siswa yang berada pada katagori baik sekali sebanyak 8 orang $(57,14 \%)$; siswa yang berada pada katagori baik sebanyak 1 orang $(7,14 \%)$; siswa yang berada dalam katagori cukup sebanyak 1 orang $(7,14 \%)$, siswa yang berada dalam kategori kurang sebanyak 3 orang $(21,44 \%)$ dan masih ada siswa yang berada dalam kategori sangat kurang sebanyak 1 orang $(7,14 \%)$. Untuk rata-rata hasil belajar siswa secara klasikal dihitung dengan rumus sebagai berikut:

$$
(\bar{X})=\frac{\Sigma X}{N}
$$

Keterangan:

$$
\begin{aligned}
& \Sigma X \quad=\text { jumlah nilai } \\
& \mathrm{N} \quad=\text { banyaknya siswa } \\
& (\bar{X}) \quad=\text { nilai rata-rata kelas } \\
& (\bar{X})=\frac{1035}{14}=73,93
\end{aligned}
$$

Daya serap siswa secara klasikal dihitung dengan rumus sebagai berikut:

$$
\begin{aligned}
\text { DS } & \begin{array}{l}
\text { Jumlah skor yang dicapai siswa } \\
\text { Jumlah total skor maksimum }
\end{array} \times 100 \% \\
\mathrm{DS}= & \frac{1035}{1400} \times 100 \%=73,93 \%
\end{aligned}
$$

Ketuntasan belajar siswa secara klasikal dapat dihitung dengan rumus:

$$
\begin{aligned}
K K & =\frac{\text { Banyaknya siswa yang tuntas }}{\text { Banyaknya siswa yang ikut tes }} \times 100 \% \\
\mathrm{KK} & =\frac{9}{14} \times 100 \%=64,29 \%
\end{aligned}
$$

Berdasarkan hasil evaluasi belajar siswa pada siklus I diperoleh penggolongan prestasi belajar siswa melalui Penilaian Acuan Patokan (PAP) skala lima pada Tabel 3.6 hasil belajar siswa dengan Penerapan Model Pembelajaran cooperative tipe Think Talk Write (TTW) dalam upaya meningkatkan aktivitas dan hasil belajar Matematika siswa kelas V Satuan Pendidikan SD Negeri 4 Seraya Barat semester Ganjil Tahun Pelajaran 2019/2020, berada pada katagori baik yang dapat disajikan pada tabel 2 sebagai berikut: 
Tabel 2. Konversi Skor Hasil Belajar Siswa Siklus I

$\begin{array}{cccc}\text { No } & \text { Rentangan Nilai } & \text { Skor Rata-Rata } & \text { Katagori } \\ 1 . & 80-100 & & \text { Baik Sekali } \\ 2 . & 66-79 & \mathbf{7 3 , 9 3} & \text { Baik } \\ \text { 3. } & 56-65 & & \text { Cukup } \\ 4 . & 41-55 & & \text { Kurang } \\ 5 . & 32-40 & & \text { Sangat } \\ & & & \text { Kurang }\end{array}$

Perbandingan prestasi belajar, daya serap, dan ketuntasan klasikal siswa pada pretest dan siklus I dapat dilihat pada grafik berikut.

Gambar 2. Grafik Hasil Belajar Siswa Siklus I

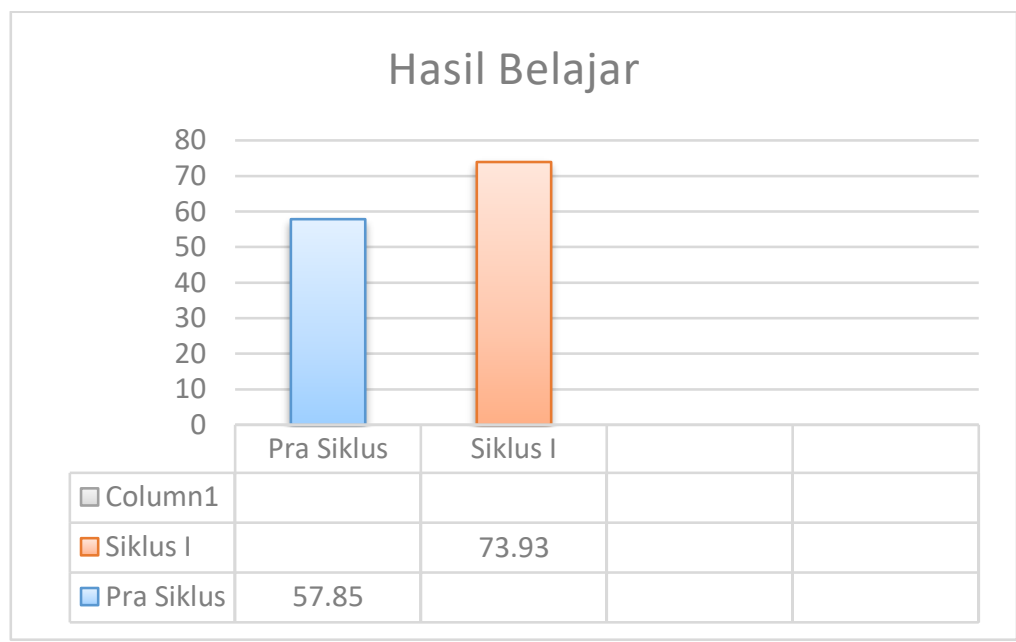

Gambar 3. Grafik Daya Serap Siswa Siklus I

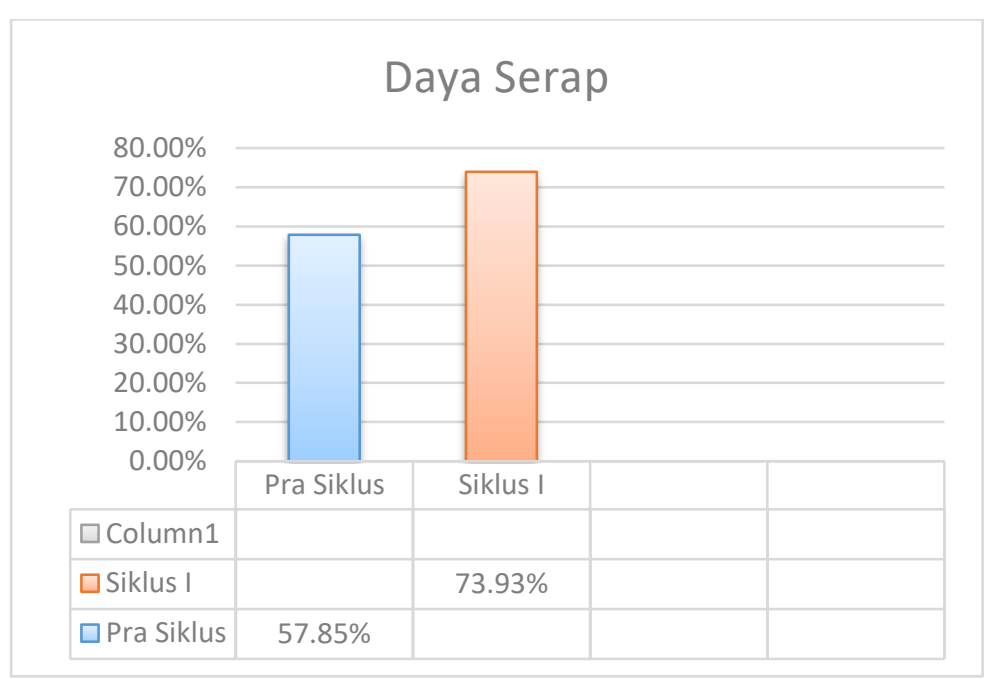


Gambar 4. Grafik Ketuntasan Klasikal Siswa Siklus I

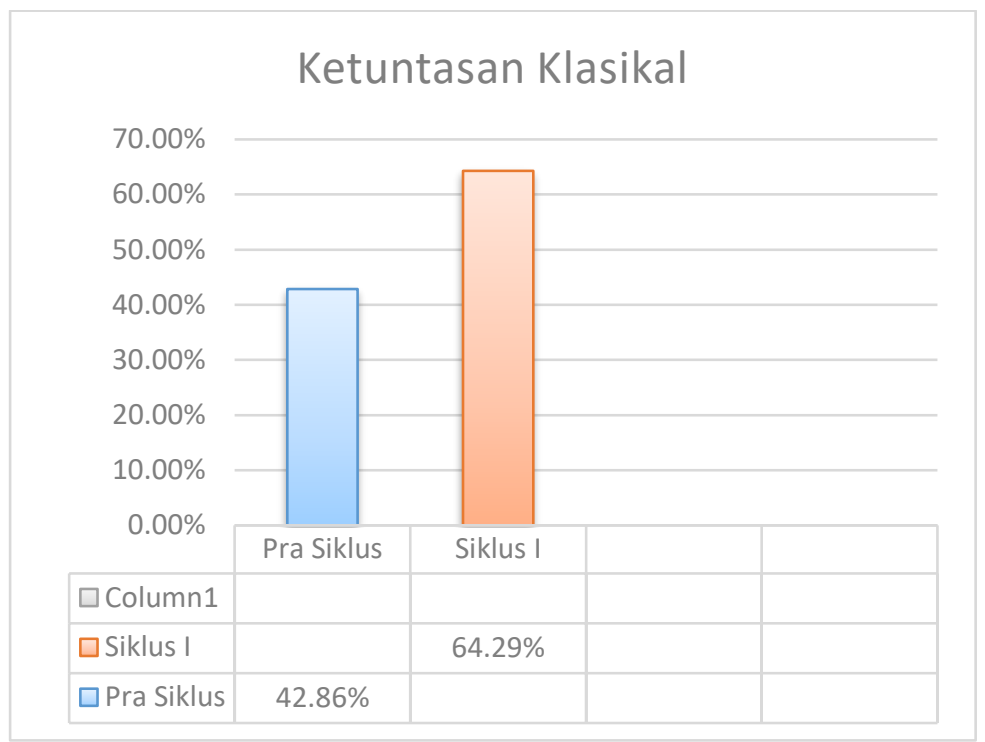

\section{c. Refleksi Siklus I}

Hasil observasi mengenai aktivitas belajar dan hasil evaluasi terhadap kegiatan belajar siswa terdapat sejumlah siswa yang belum mencapai kriteria keberhasilan yang ditetapkan. Dari 14 orang siswa ada 4 orang siswa yang masih dalam katagori kurang aktif. Sementara untuk hasil belajar Matematika ada 5 orang siswa yang tidak tuntas sesuai dengan Kriteria Belajar Minimal (KBM) 65 yang ditetapkan sekolah. Ketidakberhasilan tersebut tampaknya disebabkan oleh Penerapan Model Pembelajaran cooperative tipe Think Talk Write (TTW) oleh siswa sehingga keberanian siswa untuk berdiskusi, bertanya masih perlu ditingkatkan, serta saat berinteraksi dan berkolaborasi dengan teman untuk membahas LKS (talk) siswa masih kurang fokus dan masih suka bercanda dengan temannya, faktor yang lain masih kurangnya buku pegangan bagi siswa.

Berdasarkan hasil refleksi siklus I, pada siklus II dilakukan dengan lebih memantapkan penerapan model pembelajaran cooperative tipe Think Talk Write (TTW), yang lebih mendorong siswa agar lebih berani untuk mengemukakan pendapat dan bertanya kepada teman atau guru bila ada materi yang belum dipahami. Guru juga akan lebih memperhatikan dan memediasi setiap permasalahan yang dialami siswa sehingga kurang fokus. Keterbatasan buku pegangan diusahakan dengan memberikan ringkasan kepada siswa berupa ringkasan materi sehingga bisa dipelajari sebelumnya di rumah. 


\section{Hasil Penelitian pada Siklus II}

a. Aktivitas Belajar Siswa Siklus II

Data tentang aktivitas belajar pada siklus II diperoleh melalui lembar observasi selama kegiatan berlangsung. Lembar observasi terdiri dari 5 (lima) indikator dimana masing-masing indikator mempunyai skor maksimum 4 dan skor minimum 0 , artinya siswa diberikan skor 4 jika memenuhi keempat deskriptor yang ada pada setiap indikator dan siswa akan diberikan skor 0 jika tidak ada memenuhi keempat deskriptor yang ada pada setiap indikator. Katagori aktivitas belajar siswa ditentukan menggunakan tabel berikut.

Tabel 3. Katagori Aktivitas Belajar Siswa

$\begin{array}{cll}\text { No } & \text { Skor } & \text { Katagori } \\ \text { 1. } & \bar{X} \geq 15,00 & \text { Sangat Aktif } \\ \text { 2. } & 11,67 \leq \bar{X}<15,00 & \text { Aktif } \\ \text { 3. } & 8,34 \leq \bar{X}<11,67 & \text { Cukup Aktif } \\ \text { 4. } & 5,01 \leq \bar{X}<8,34 & \text { Kurang Aktif } \\ \text { 5. } & \bar{X}<5,01 & \text { Sangat Kurang Aktif }\end{array}$

Tabel 4. Kriteria Skor Aktivitas

$\begin{array}{cll}\text { No } & \text { Skor Aktivitas } & \text { Katagori Aktivitas } \\ \text { 1. } & 15-20 & \text { Sangat Aktif } \\ \text { 2. } & 11,67-14,99 & \text { Aktif } \\ \text { 3. } & 8,34-11,66 & \text { Cukup Aktif } \\ \text { 4. } & 5,01-8,33 & \text { Kurang Aktif } \\ 5 . & 0-5 & \text { Sangat Kurang Aktif }\end{array}$

Berdasarkan perolehan aktivitas belajar siswa tersebut dapat diketahui bahwa siswa yang berada pada katagori sangat aktif sebanyak 7 orang $(50,00 \%)$; siswa yang berada pada katagori aktif sebanyak 4 orang $(28,57 \%)$, siswa yang berada dalam katagori cukup aktif sebanyak 3 orang $(21,43 \%)$ dan siswa yang berada dalam kategori kurang aktif sebanyak 0 orang $(0,00 \%)$.

Kemudian dari skor yang diperoleh dicari rata-ratanya untuk mengkatagorikan sejauh mana aktivitas belajar siswa terhadap Penerapan Model Pembelajaran cooperative tipe Think Talk Write (TTW) dalam pembelajaran Matematika siswa kelas V Satuan Pendidikan SD Negeri 4 Seraya Barat semester ganjil Tahun Tahun Pelajaran 2019/2020. Untuk lebih jelasnya, data aktivitas siswa dihitung dengan rumus sebagai berikut. 
$\bar{X}=$

$\frac{\Sigma X}{N}$

Keterangan:

$\bar{X} \quad=$ nilai rata-rata kelas

$\Sigma X \quad=$ jumlah nilai siswa keseluruhan

$\mathrm{N}=$ jumlah siswa

$\bar{X}=\underset{\frac{\Sigma X}{N}}{ }=\frac{202}{14}=14,43$

Sesuai dengan kriteria aktivitas,tingkat kategori aktivitas siswa dengan Penerapan Model Pembelajaran cooperative tipe Think Talk Write (TTW) dalam upaya meningkatkan aktivitas dan hasil belajar matematika siswa kelas V SD Negeri 4 Seraya Barat semester ganjil Tahun Pelajaran 2019/2020, pada siklus II tergolong aktif, yang tampak melalui grafik di bawah ini.

Gambar 5.Grafik Aktivitas Belajar Siswa Siklus II

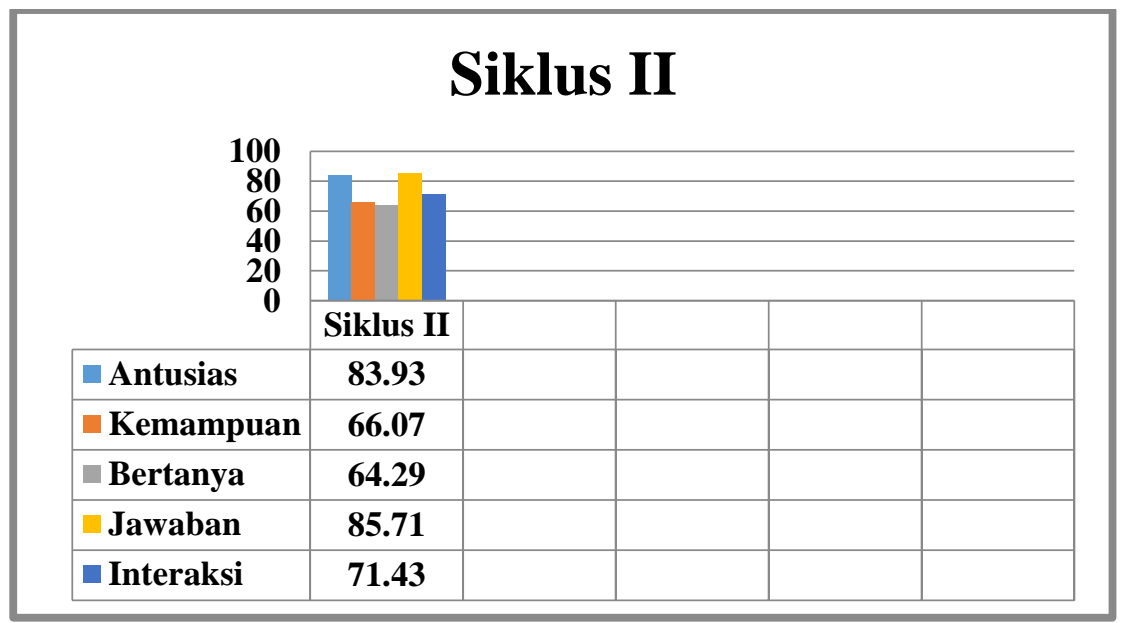

b. Hasil Belajar Siswa Siklus II

Hasil belajar siswa pada siklus II dalam penerapan model pembelajaran cooperative tipe Think Talk Write (TTW) dalam upaya meningkatkan aktivitas dan hasil belajar Matematika siswa kelas V SD Negeri 4 Seraya Barat semester Ganjil Tahun Pelajaran 2019/2020, yang dikumpulkan melalui tahap evaluasi siklus II diperoleh skor 1265 dengan skor maksimum idealnya adalah 1400 dan skor minimal idealnya adalah 0 yang sudah dikonversikan ke dalam skor 100. Salah satu contoh pengolahan hasil belajar siswa adalah sebagai berikut. 
Skor mentah

$X S 1=, \overline{\text { soal }} \times 100$
15

$\mathrm{XS} 1=-\times 100=75$

Berdasarkan perolehan hasil belajar dapat diketahui bahwa siswa yang berada pada katagori baik sekali sebanyak 12 orang $(85,71 \%)$; siswa yang berada pada katagori baik sebanyak 2 orang (14,29\%); siswa yang berada dalam katagori cukup sebanyak 0 ( $0,00 \%)$; dan siswa yang berda dalam kategori kurang sebanyak 0 ( $0 \%)$. Untuk rata-rata hasil belajar siswa secara klasikal dihitung dengan rumus sebagai berikut:

$(\bar{X})=\frac{\Sigma X}{N}$

Keterangan:

$\Sigma X \quad=$ jumlah nilai

$\mathrm{N}=$ banyaknya siswa

$\bar{X} \quad=$ nilai rata-rata kelas

$(\bar{X})=\frac{1265}{14}=90,36$

Daya serap siswa secara klasikal dihitung dengan rumus sebagai berikut:

$$
\begin{aligned}
D S & =\begin{array}{l}
\text { Jumlah skor yang dicapai siswa } \\
\text { Jumlah total skor maksimum }
\end{array} \times 100 \% \\
\mathrm{DS} & =\frac{1265}{1400} \times 100 \%=90,36 \%
\end{aligned}
$$

Ketuntasan belajar siswa secara klasikal dapat dihitung dengan rumus:

$$
K K=\frac{\text { Banyaknya siswa yang tuntas }}{\text { Banyaknya siswa yang ikut tes }} \times 100 \%
$$

$\mathrm{KK}=\frac{14}{14} \times 100 \%=100 \%$

Berdasarkan hasil evaluasi belajar siswa pada siklus II diperoleh penggolongan hasil belajar siswa melalui PAP skala lima, hasil belajar siswa dalam pembelajaran Matematika melalui penerapan model pembelajaran cooperative tipe Think Talk Write (TTW) dapat meningkat dan semua siswa dapat dikategorikan tuntas. Hasil belajar matematika siswa kelas V SD Negeri 4 Seraya Barat semester ganjil 2019/2020, berada pada kategori baik sekali. Perbandingan hasil belajar, daya serap, dan ketuntasan klasikal siswa pada pre-test, siklus I, dan siklus II dapat dilihat pada grafik berikut. 


\section{Gambar 6.Grafik Hasil Belajar Siswa Siklus II}

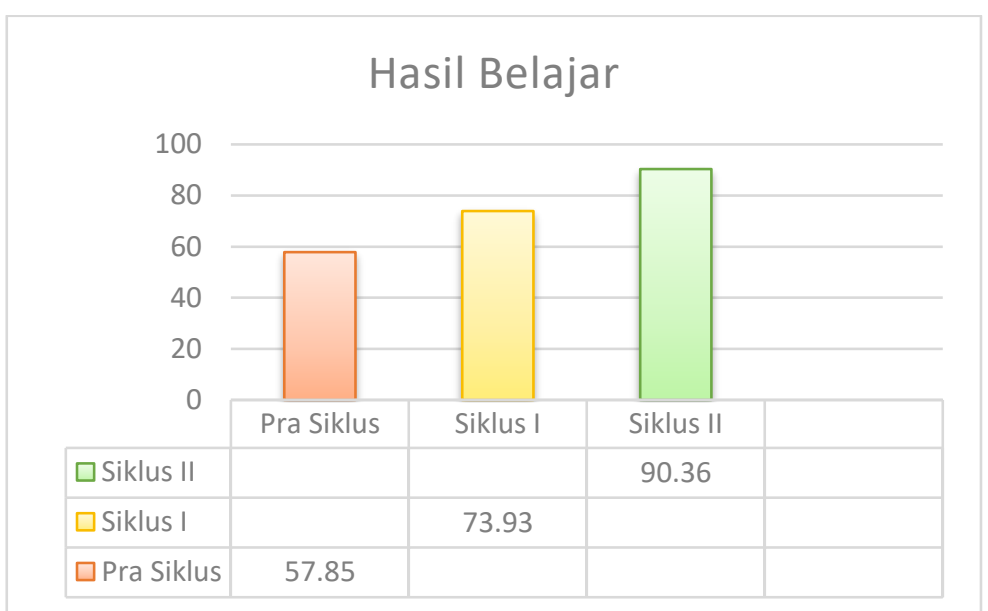

Gambar 7. Grafik Daya Serap Siswa Siklus II

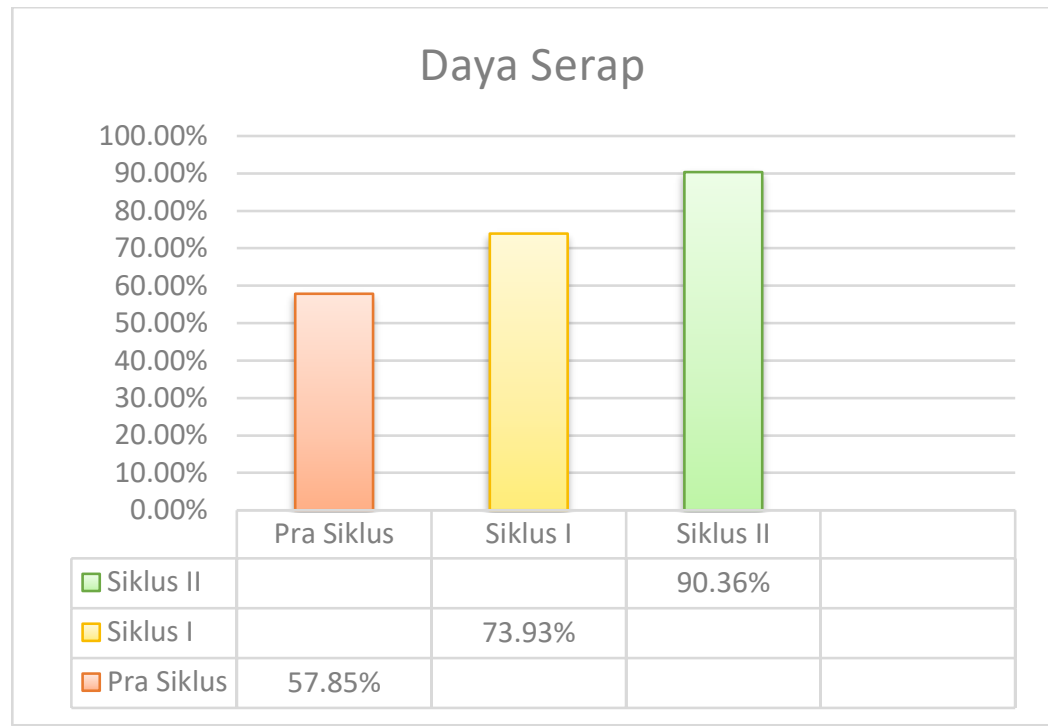

Gambar 8. Grafik Ketuntasan Klasikal Siswa Siklus II

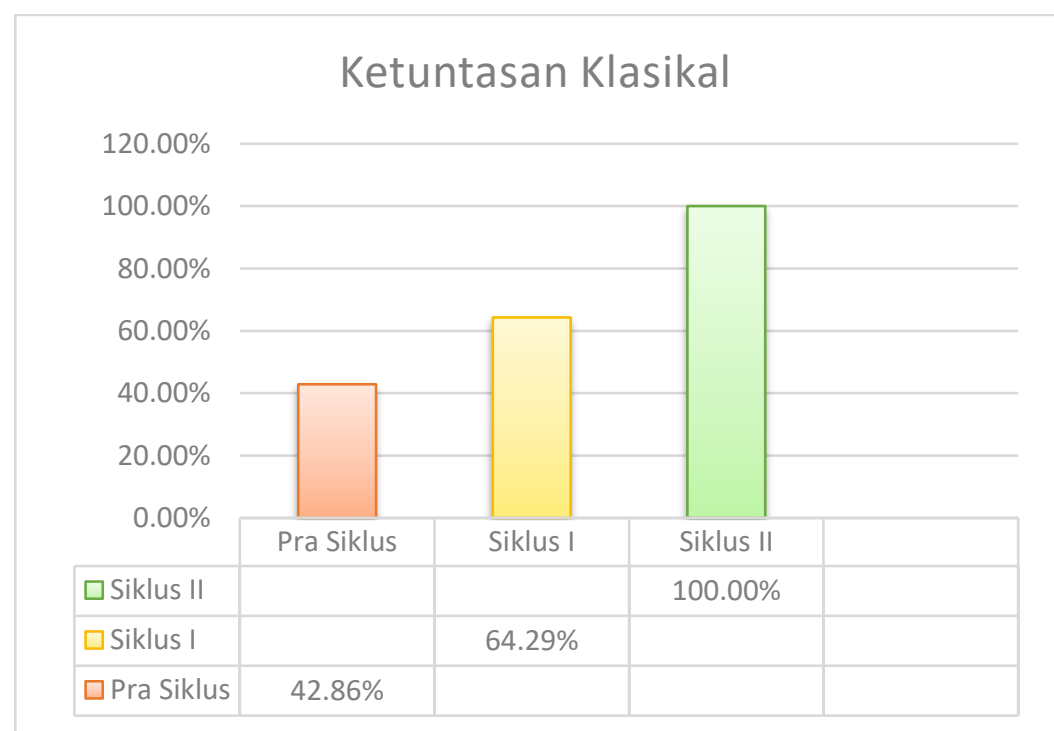


Berdasarkan hasil-hasil yang diperoleh tersebut, menunjukkan bahwa Penerapan Model Pembelajaran cooperative tipe Think Talk Write (TTW) dalam pembelajaran Matematika pada siswa kelas V Satuan Pendidikan SD Negeri 4 Seraya Barat dapat meningkatkan aktivitas siswa dari rata-rata 10,64 pada siklus I menjadi 14,43 pada siklus II. Jadi, ada peningkatan sebesar 3,79 Penerapan strategi Think Talk Write (TTW) dalam pembelajaran Matematika pada siswa kelas V Satuan Pendidikan SD Negeri 4 Seraya Barat dapat meningkatkan hasil belajar Matematika adalah 73,93 pada siklus I menjadi 90,36 pada siklus II. Jadi ada peningkatan sebesar 16,43 Ketuntasan klasikal pada siklus I adalah 64,29\% menjadi $100 \%$ pada siklus II. Jadi ada peningkatan sebesar 35,71\% dan ditinjau dari langkah-langkah yang terjadi dalam pembelajaran Think Talk Write (TTW) di kelas yang menekankan siswa untuk berinteraksi kepada kelompoknya. Sesuai dengan tahapan model pembelajaran cooperative tipe Think Talk Write (TTW) secara individual, siswa bertanggungjawab untuk memikirkan (think) ide-ide menyelesaikan masalah sesuai pengetahuan awalnya yang difasilitasi dengan LKS. Kemudian siswa berinteraksi dan berkolaborasi dengan teman untuk membahas LKS (talk), dalam posisi ini peneliti hanya berperan sebagai mediator lingkungan belajar. selanjutnya, siswa mengkonstruksi sendiri pengetahuan sebagai hasil kolaborasi berupa catatan kelompok dan rangkuman hasil belajar (write). Sehingga dalam pembelajaran ini melibatkan siswa untuk berpikir kritis, aktif dan membengkitkan rasa percaya diri siswa melalui diskusi kelompok.

\section{Kesimpulan}

Berdasarkan hasil analisis data dan pembahasan penelitian ini dapat ditarik simpulan sebagai berikut. 1) Penerapan model pembelajaran cooperative tipe Think Talk Write (TTW) dalam pembelajaran matematika dapat meningkatkan aktivitas belajar siswa kelas V SD Negeri 4 Seraya Barat semester ganjil tahun pelajaran 2019/2020. Aktivitas belajar siswa pada Siklus I adalah 10,64 sedangkan aktivitas belajar siswa pada siklus II adalah 14,43. Dengan demikian terjadi peningkatan sebesar 3,79 dari siklus I ke siklus II. 2) Penerapan model pembelajaran cooperative tipe Think Talk Write (TTW) pada pembelajaran matematika dapat meningkatkan hasil belajar siswa kelas V SD Negeri 4 Seraya Barat semester ganjil tahun pelajaran 2019/2020. Hasil belajar siswa pada siklus I adalah 73,93 sedangkan hasil belajar siswa pada siklus II adalah 90,36. Dengan demikian terjadi peningkatan sebesar 16,43 dari siklus I ke siklus II. 


\section{Daftar Pustaka}

Abimanyu, Soli dkk. (2007). Strategi Pembelajaran. Jakarta: Departemen Pendidikan Nasional.

Agung. (1999). Metodologi Penelitian. Surabaya: Usada Nasional.

Agung, A. A. Gede. (2011). Metodologi Penelitian Pendidikan. Singaraja: FIP Undiksha Singaraja.

Ahmai, Abu dan Ubiyati Nur. (1999). Ilmu Pendidikan. Jakarta: Rineka Ciptta.

Arikunto, S. (1999). Dasar-Dasar Evaluasi Pendidikan. Yogyakarta: Bumi Aksara.

Arikunto, S. (2003). Manajemen Penelitian. Jakarta: PT Rineka Cipta.

Arikunto, S. (2005). Dasar-Dasar Evaluasi Pendidikan. Bandung: Bina Aksara.

Arikunto, S. (2006). Prosedur Penelitian Suatu Pendekatan Praktik. Jakarta: PT Rineka Cipta.

A.M. Sardiman. (1986). Interaksi dan Motivasi Belajar Mengajar. Jakarta : CV.Rajawali. Bernadib, Imam. (1988). Filsafat Pendidikan, Sistem dan Metode. Yogyakarta : Andi Offset

Daryanto, H.M. (2006). Administrasi Pendidikan. Jakarta. Rineka Cipta.

Depdiknas. (2003). Undang-Undang RI No.20 Tahun 2003. Tentang sistem pendidikan nasional

Depdiknas. (2006). Permendiknas No.22 Tahun 2006 Tentang Standar Isi Jakarta:Depdiknas

Dimyati dan Mudjiono. (1992). Belajar dan Pembelajaran. Jakarta : Rineka Cipta

Fatmawati, D.N. (2010). Penerapan Strategi Pembelajaran Think Talk Write Untuk Meningkatkan Aktivitas Belajar Biologi Siswa Kelas X-1 SMA Al Islam 1 Surakarta Tahun Ajaran 2009/2010.

Hamalik. Oemar. (2004). Proses Belajar Mengajar. Bumi Aksara.Jakarta

Koyan. (2007). Statistik Terapan Teknik Analisis Data Kuantitatif. Singaraja: Undiksha Lie, Anita. (2005). Mempraktikkan Cooperative Learning Di Ruang-Ruang Kelas. Jakarta: Penerbit PT Gransindo.

Marisanita S, Dian. (2009). "Penerapan strategi think talk write (TTW) dalam Pembelajaran matematika ditinjau dari Minat belajar siswa". Skripsi (diterbitkan). Jurusan Matematika Fakultas keguruan dan ilmu pendidikan Universitas muhammadiyah Surakarta. 
Moedjiono, \& Moh. Dimyati. (1992). Strategi Belajar Mengajar. Jakarta: Depdikbud Derektorat Jendral Pendidikan Tinggi Proyek Pembinaan Tenaga Kependidikan. Nurkancana dan Sunartana. (1990). Evaluasi Hasil Belajar. Surabaya: Usaha Nasional.

Raka Rasana, I D P. (2009). Laporan Sabbatical Leave Model-Model Pembelajaran. FIP UNDIKSHA Singaraja.

Sadra, I W dkk. (2010). Laporan Penelitian PIPS Implementasi Pembelajaran Matematika Realistik dengan Strategi TTW Berbantuan Jurnal Mingguan dalam Rangka Meningkatkan Kemampuan Koneksi dan Komunikasi Siswa SMKN 2 Singaraja. UNDIKSHA Singaraja.

Santrock. (2008). Psikologi Pendidikan. Jakarta: Kencana.

Suciati dan Prasetya Irawan. (2005). Interaksi dan Motivasi Belajar Mengajar , Jakarta, PT Raja Grafindo Persada.

Sudjana, Nana. (2004). Penilaian Hasil Proses Belajar Mengajar. Bandung: PT Remaja Rosdakarya.

Sukardi. (2009). Metodologi Penelitian Pendidikan. Jakarta: PT Bumi Pustaka.

Suprayekti. (2003). Interaksi Belajar Mengajar. Jakarta. Direktorat Tenaga kependidikan, Dikdasmen. Depdiknas

Trianto, (2007). Model-Model Pembelajaran Inofatif Berorientasi Konstruktivistik. Jakarta: Pustaka Prestasi.

Wibawa, B. (2003). Penelitian Tindakan Kelas. Jakarta: Depdiknas.

Wahyudin, H., dkk. (2004). Pengantar Pendidikan. Jakarta : Universitas Terbuka.

Wardani, IGAK. dkk. (2004). Materi Pokok Penelitian Tindakan Kelas. Jakarta: Universitas Terbuka (UT).

Zuhairini, H., dkk. (1983). Metodik Khusus Pendidikan Agama. Malang : Biro Ilmiah Fakultas Tarbiyah IAIN Sunan Ampel Malang. 